\title{
Pärimusmeditsiin ja globaliseeruvad tervisetrendid
}

\author{
Mare Kõiva \\ Eesti Kirjandusmuuseumi folkloristika osakonna juhtivteadur \\ mare@folklore.ee
}

\begin{abstract}
Teesid: Artikkel lähtub Frederick Dunni kosmopoliitse meditsiini käsitlusest ja vaatleb, kas ja kuidas sobib termin iseloomustama üleilmastuvaid naabervaldkondi, pärimus(ja alternatiiv)meditsiini. Tänapäeva alternatiivmeditsiini raames levivad jooga, hiina meditsiin, ajurveda, muusikateraapia jm õpetused, pikema ajalooga on kohapeal homöopaatia ja mitmed naturopaatia õpetused neid vahendab Eestisse kultuuriline sidusus ja rahvusvahelistumine. Tänase etno- ja alternatiivmeditsiini omadus on tähelepanu keskendumine inimese terviklikkusele, mentaalsuse kujunemisele ja tervisekäitumisele.

Traditsioonilise ja täiendmeditsiini praktika institutsionaliseerumise kõrval on märgatav kursuste liikumine linnast maapiirkonna tervisekeskustesse. Teadmiste eelduspärane põhiväärtus on nende iidsus, mille raames kombineeritakse erinevaid võtteid. Osa kursusi integreerib kohalikke rahvameditsiini ja folkloori võtteid või põhineb nendel. Rõhutatakse kohaliku etnomeditsiini pakutavaid võimalusi, millele antakse uusi kultuurilisi tõlgendusi. Põhisuundumused: a) kohalik teadmine ja ravivõtted moodustavad segmendi Eestis kasutatavast alternatiivmeditsiinist ja vaimse arengu suundadest; $b$ ) tähtsustatud on tervisekäitumine ja haigusi ennetav eluviis (saunakultuur, ravimtaimed, linnastressist vabanemine looduskeskkonnas, algupärane muusikateraapia, jutustamine kui tasakaalustamisviis, ökoloogilise toidu tarbimine) ja c) alternatiivse maailmapildi vahendamine, füüsilise ja vaimse külje arendamine, vaimse enesearengu toetamine, vaadete pluralism. Artikkel iseloomustab tendentse aastail 2015-2017.
\end{abstract}

Märksõnad: etnomeditsiin, komplementaarne meditsiin, kosmopoliitne meditsiin, pluralistlik pärimusmeditsiin

Probleemide lahendamise otsingutel pöördutakse üha enam loodusravi ja traditsioonilise meditsiini poole, saamaks loomulikku ravi võimalikult väheste kaasuvate toimetega. Huvi traditsiooniliste rahvateadmiste vastu on arenenud paralleelselt sotsiaal-kultuuriliste liikumistega, mis pööravad tähelepanu keha ja hinge võrdsele arendamisele ning tasakaalustatud ja tervislikule eluviisile.

Permakultuur ja ökokülade liikumine on tänase elustiilide pluralismi osa (Walsh 2016), mis toetab tervise alalhoiu ja terve eluviisi liikumist. Meditsiinivaldkonnas esindavad muutusi alternatiiv- ja komplementaarsed suunad. Otseselt haigustele ja nende ravimisele suunatud ja meditsiiniteadmisi jagavate kursuste kõrval eksisteerivad tervet eluviisi toetavad üritused - kõike seda 
prognoosisid Sara Cant ja Ursula Sharma 1999. aastal avaldatud uuringus "Uus meditsiiniline pluralism?" (Cant \& Sharma 1999).

Kuidas iseloomustatakse alternatiiv- ja täiendmeditsiini? Ryan Abbot ja tema kaasautorid (2011) on iseloomustanud valdkondi neljateistkümne põhiväärtuse kaudu: 1) terviklik ja individuaalne lähenemisviis patsiendi eest hoolitsemisele; 2) usk keha kaasasündinud paranemisvõimesse; 3) elukestev tervise eest hoolitsemine kui ravi; 4) haigused on seotud vaimsusega; 5) patsientide aktiivse osalisena kaasamine; 6) patsientidele lootuse andmine; 7) humanistlik, suhetekeskne patsientide ja ravijate interaktsioon; 8) patsientidele tervislike eluviiside modelleerimine; 9) täiend- ja alternatiivse meditsiini ja allopaatilise meditsiini koostoime; 10) biomeditsiinilistest uuringutest erinev tõenduspõhisus; 11) ravijate kompetentsus täiend- ja alternatiivmeditsiini põhiteadmiste osas; 12) rõhutatakse ennetava meditsiini tähtsust; 13) keskendutakse tervisele ja heaolule, haiguse puudumisele; 14) ravi on olemuselt väheinvasiivne.

Vaatlen artiklis, kuidas positsioneerub loodusteraapia kursustel traditsioonilise meditsiini nimetuse all õpitav rahvameditsiin. Millist osa pärimuskultuuri võtetest rakendatakse ravimisel, tervise parandamisel või isiksusliku arengu toetamisel. Kuna arvestatav osa tervist toetavatest võtetest on globaalse levikuga, kasutan põhiterminina globaalset alternatiivmeditsiini. Käesolev kirjutis põhineb ennekõike perioodi 2015-2017 tendentsidel ja erinevatest suundadest on toodud esile mõned iseloomulikumad näited. Tulevikus on perspektiivne vaadelda, missugune osa erinevatest globaalsetest võtetest sulatatakse kohalikesse teadmistesse ja kas neile luuakse kohalikke alternatiive.

Neil teemadel sõna võtmine on enam kui akuutne, arvestades mõjuisikute ajakirjanduses vahendatud sõnavõtte, tihti ühekülgseid hinnanguid, mis seavad kahtluse alla tervisekäitumise vaimset arengut soosiva poole. ${ }^{1}$ Tõenduspõhine meditsiin ei paku hetkel tervikkäsitlusi linnastunud ja istuva või suhteliselt piiratud liikumistrajektooriga inimese tervise, haiguste ja ravimisviiside kohta, ka puudub käepärane terviklik ülevaade ametlike medikamentide kohta. Füüsilise tervise kõrval vajavad uusi käsitlusi ka vaimne tervis ja inimese areng. Teatavasti on mõistuseta keha üks meie aja tunnus ja probleem.

\section{Üldmuudatused rahva- ja komplementaarmeditsiinis}

1976. aastast on leidnud rakenduse oskuskeelend "kosmopoliitiline meditsiin" (vrd Dunn 1976; Tan 1989, Wilce 2009: 207), ${ }^{2}$ selle kõrval kasutatakse alternatiivina terminit "biomeditsiin", mis põhineb Michel Foucault'i filosoofilisel tõlgendusel (Foucault 2003 [1963]). Mõlemad oskuskeelendid iseloomustavad ametliku "lääne" meditsiini ja ravimite globaalset levikut. Meedik ja antropoloog 
Frederick Dunn märkis: "Kosmopoliitset meditsiini iseloomustab ülemaailmne ja piiramatu levik ja kasutamine; see puudutab maakera paljudes kohtades elavaid inimesi. Lääne meditsiini iseloomustab kõrgtehnoloogiate kasutamine ja oma suundade juurutamine maailma erinevates osades." (Dunn 1976: 135).

Dunni arvates on meditsiini kosmopoliitsuse põhjuseks kapitalismi võimas ekspansioon 20. sajandil. Samal ajal ei ole kosmopoliitne meditsiin globaalselt homogeenne, sellel on kohalikud regionaalsed eripärad ning see varieerub, kuid lisaks professionaliseerumisele ja spetsialiseerumisele on selle eripära, et ta allutab ja kaotab kohaliku ja regionaalse meditsiini vorme.

Dunn asetas rahva- ehk traditsioonilise meditsiini ühte ritta kosmopoliitilise meditsiiniga ja rõhutas, et vaatamata eelarvamustele ja katsetele need kaks süsteemi vastandada ja pidada neid dualismi erinevateks tahkudeks, leidub hiina meditsiinis, ajurvedas jm teaduselemente, ametlikku meditsiini aga võib teatud mõttes samastada kunstiga. Suurt tähtsust omab fakt, et erinevad meditsiiniliigid asetatakse Dunni lähenemises ühele tasemele. Tema tõlgenduses ei ole vastandavat hierarhiat, kus ametlikku kosmopoliitilist meditsiini hinnatakse kõrgema, ülejäänud meditsiini aga madalama valdkonnana.

Samas ei viita Dunn kaasaegse alternatiiv- ja rahvameditsiini puhul üldmeditsiiniga sarnastele arengujoonetele, kus kosmopoliitsus on märgilise tähtsusega tunnus. Laialdane levik on üks põhjus, miks diferentseerin kosmopolitismi kaasaegse pluralistliku rahvameditsiini tähtsa tunnusena - ka selle suunad on laialdaselt levinud, levik on progresseeruv ja menetluslik, mitmeid suundi iseloomustavad rahvusvahelised võrgustikud. Hea näide on jooga suundade progresseeruv levik.

Möödunud sajandit iseloomustas “terviseturul” varasematest globaalsemate teadmiste, suundade ja uute võtete integreerimine endistesse rahvameditsiini praktikatesse, samuti alternatiivse ja komplementaarse (täiend-) meditsiini tähtsuse üldine kasv. 21. sajandil on selle suuna kasutajate arv erinevates riikides pigem kasvanud (vt Nissen 2011; Cant \& Sharma 1999; Astin 2000; Coulter \& Willis 2007; Falci \& Shi \& Greenlee 2012; Klein et al. 2015; Toupin \& Gaboury 2013; NN 2015). Näiteks kasutas Šveitsis aastail 2002-2017 komplementaarse meditsiini erinevaid võimalusi umbes $25 \%$ isikutest, kelle vanus algas 15 eluaastast (Klein et al. 2015).

Meditsiin on üks üleilmastumise näiteid, kus paljud nähtused levivad kultuurilise kosmopolitismi vahendusel, nagu näiteks Eestisse jõudnud esoteerilised õpetused (Abiline 2013), homöopaatia ja jooga (Vahesaar 2016), ajurveda, muusikateraapia, hiina meditsiin või massaaži erinevad suunad (vt käesolevas numbris Kartau 2019), uusi taimravi viise kasutav fütoteraapia, lille- ja aroomiteraapia, ravisalvide valmistamine ja muud võtted (Kõiva, ilmumas). 
Loodusravi ei ole tänapäeval enam peresisene tegevus või pöördumine lähima rahvaarsti poole, vaid osalemine kursustel, kust saadakse mitmekülgseid teadmisi tervise ja haiguste kohta. Kaasaegseid alternatiivsuundi ja kursusi iseloomustavad ühistendentsid nagu institutsionaliseerumine ja professionaliseerumine, litsentseeritud spetsialistid, kes valdavad erinevaid tehnikaid ja rakendavad neid praktikas, tihti on tegemist mitme tehnika sulamiga, mida individuaalselt edasi arendatakse.

Uuemate Euroopas ja Ameerikas levinud ühisjoonte hulka kuulub erinevate kursuste ja raviseansside üleviimine linnast maale: turismi- ja tervisetaludesse ja väiksemates kohtades paiknevatesse spaakeskustesse. Seda soosib kommunikatsiooni areng ja informatsiooni levimise uued võimalused, aga ka transpordiolud. Täpselt ühepikkune teekond on maalt linna või linnast linna, ja üldiselt käiakse maakohtadest meelsasti linnas kursustel. Seda sümpaatsem on maakoha tähtsuse tõusmine, mis on oluline uuendus ja vastab kõikides tahkudes kaasaegse ühiskonna vajadustele: on võimalus korraldada rituaale, olla eraldatud, teistsugune keskkond, kontakt loodusega, mälu ja isiksuse arendamise teistsugused võtted, kuulub uute elulaaditrendide juurde.

\section{Institutsionaliseerimise katsed}

1980. aastast püütakse Eestis luua rahvameditsiini ühendust, kuhu kuuluks praktiseerivaid meedikuid, terapeute, rahvaravitsejaid ja teadlasi. Alternatiivina prooviti kujundada ühendust, kuhu kuuluksid rahvaravitsejad, selgeltnägijad (ja teadlased). Ühenduse eesmärgiks määrati vastastikune koostöö ja õigus rahvaravitsejatele/loitsijatele litsentse väljastada; tähtsaks momendiks peeti legaalsete koolituskursuste korraldamise õigust.

Katsed registreerida ühendus ja alustada tööd olid lühiealised: ravitsejatel ei jätkunud aega, väljapool konkreetsete ürituste raame oli keeruline leida aega sotsiaalseks suhtluseks, ravijad elasid Eesti erinevates piirkondades, maailmavaate ja meditsiiniliste võtete vaatepunktist olid kasutusel erinevad lähenemised, ka oli suurtel ja väljapaistvatel isiksustel mõnigi kord keerukas teha omavahel koostööd. Ravitsejate ühinemise takistuseks oli pika aja vältel erimeelsuste rohkus. Ka ei soodustanud bürokraatlik mehhanism ühenduse eluvõimet ning lõppude lõpuks (Eesti Vabariigi aastapäeval) otsustas ühendus kasutada oma sissetulekuid vähemalt ühingu eest riigilõivu tasumiseks. Tegevuse alguses ei pretendeeritud majandus- ja turundustegevuse arendamisele, kuna tuntud ravitsejatel oli oma klientuur ning nende juurde vastuvõtule saamiseks oli pikk järjekord. 
Kuigi ühtse katuse all esinemine oli pikka aega katsetamisjärgus, toimisid teised ühistöö vormid juba aastakümneid, mille hea näide on šamaanipäevade institutsioon või Eesti Nõidade Liit, kes näiteks korraldab igakuiseid nõidade konverentse (viimatised üritused 21. novembril 2019 Paides ja 5. detsembril 2019 Tartus). Tegemist on kolmikliiduga, kes tegeleb tervendava muusikaga. Viimase kahekümne aasta jooksul on registreeritud hulgaliselt erinevate alternatiivmeditsiini suundade ühendusi (muuhulgas Tiibeti meditsiinikeskus Men Ling, aroomiteraapia jm).

2008. aastal loodi rahvameditsiini ühendus (MTÜ Eesti Pärimusmeditsiini Ühing), kuid erinevaid teraapiasuundi ühendab Eesti Täiendmeditsiini ja Loodusravi Nõukoda, mis väljastab loodusravi valdkonnas ka standardseid sertifikaate. Mõjukamateks loodus- ja rahvameditsiini koolideks on Põlistarkuste ja Rahvaravi kool (kursusi korraldatakse Põhja- ja Lõuna-Eestis, enamjaolt väiksemates asulates ja maakohtades) ja Lahemaa tervisekoolist väljakasvanud Krautmani Massaaži-ja Terviseakadeemia (mille koolituskeskused paiknevad Tallinnas ja Tartus). Kursuse lõpetaja saab vastava kvalifikatsioonitunnistusega ravitsejaks ja terapeudiks. Erialaainetest õpitakse kursustel muinaseesti massaaži aluseid ja võtteid, erinevaid loodusteraapiaid, ravimtaimi, verbaalseid teraapiaid ja läbitakse eesti kombestiku alane õpe. Teisel õppeaastal omandatakse põhjalikumaid teoreetilisi teadmisi nõudvad oskused, näiteks hirudoteraapia, aadrilaskmine ja terapeutiline massaaž. Üldainetes antakse algteadmisi selleks, et alustada terapeudikarjääri iseseisva ettevõtjana. Terve rea teraapialiikide osas tavapraktikaid sakraliseeritakse ja tõstetakse eristaatusesse (saunatavad). Terviseakadeemia õppeprogrammi põhiosa koosneb ametliku meditsiini kohta käivate teadmiste tutvustamisest, tähtsa osa moodustab traditsioonilise rahvameditsiini teemade, samuti kultuuriloo tutvustamine.

Sänna tervise ja teraapia suvekooli korraldatakse augustikuu kolmandal päeval Lõuna-Eestis asuvas Sänna kultuurimõisas. Osalema kutsutakse kõiki terapeute, massööre, terapeutika õpilasi ja terviseküsimustest huvitatud isikuid, "kellele on tähtis terviklik lähenemine tervisele, inimesele ja kogu maailmale sealhulgas". Suvekoolis osalejate pereliikmetele pakutakse kultuuriprogrammi lähiümbruses. 


\section{Kohaliku tunnustamine}

Globaliseerimise tähtsaks eripäraks on uute laialdaselt tunnustatud õpetuste ja meditsiiniteenuste praktikate toomine turule ja kohalike algatuste internatsionaliseerumine. Seda suunda iseloomustab asjaolu, et kuulsate Ameerikast ja Lääne-Euroopast tulnud õppejõudude kõrval osaleb Eestis läbiviidavatel üritusel näiteks Peterburist pärit õppejõud Sergei Strekalov, aga ka tema õpilased, nt temalt innustust saanud Tõnu Talimaa jpt. Eesti ürituste transnatsionaliseerimise ja transkultuurilisuse ilminguna kasvab iga aastaga välismaa esinejate nimekiri. Lisaks vanadele tuttavatele, kes osalevad üritustel juba üle kümne aasta nagu indiaanlane Flying Eagle (Lendav Kotkas), saabuvad kõikidelt kontinentidelt uued esinejad. Reisivate õpetajatena tegutsevad ka mõned eestlased, levitades oma vaateid ja metoodikat uutele territooriumitele, nende hulka kuulub muuhulgas üks tervisekäitumise populaarsemaid isikuid - Lilleoru kommuuni juht Ingvar Villido, samuti käisid välismaal õpetamas Mikk Sarv, Kristel Vilbaste jt.

Sarnaselt karismaatiliste uute usundite ahelana ühest riigist teise levivatele seminaridele, konverentsidele ja festivalidele laienevad ka tervisesarjad. Heaks näiteks oli "Leia ennast", mis reklaamis ennast paljudele loodusravi ja (enese)tervendamise kursustele tunnusliku kreedo abil:

Sari on avatud erinevatele maailmavaadetele, keeltele ja koolidele. Teemad: vaimne areng ja enesetäiendus, loodusega suhtlemine, tervendavad ja psühholoogilised praktikad, millede eesmärgiks on enda ja meid ümbritseva maailma mõistmine, samuti hingelise tasakaalu saavutamine (Leia ennast 2017, lehekülg ei ole enam kättesaadav).

Samalaadne sari "Круг жизни” alustas laienemist Valgevenesse, integreerimaks oma süsteemi sealset rikkalikku loodusravi praktikat (Круг жизни 2017).

Märkimisväärne on kursuste laienemine vene kultuuril põhinevate teadmiste suunas. Ka vene keeles korraldatavate kursuste juures on märgatav liikumine pealinnast tervisetaludesse, mis lisaks kohalikele venekeelsetele elanikele on orienteeritud "tervendavale turismile".

Põlistarkuste kool sõnastas oma eesmärki nii - avaldada austust tarkusele ja teadmistele, samuti nende kandjatele, kes elasid veel ammu enne meid. "Mõned teadmised on niivõrd laialdased ja sügavad, et tuues ja integreerides neid tänasesse päeva, võime muuta oma elu, samuti oma lähedaste ja klientide elu" (Põlistarkuste kool 2017).

Lisaks kosmopolitismile ehk oma territooriumi ja kultuuri globaliseerimise raames esitamisele tunnustatakse kohaliku rahvameditsiini võimalusi, mis rõhutab põlisväärtusi ja loob uusi kultuuritõlgendusi. 
Selle tunnusena võib tuua esile, et ravikursused reklaamivad, et nad jätkavad: a) traditsioonilise meditsiini kasutamist; b) kohaliku (iidse) saunakultuuri õpetamist; c) õpetavad taimede ja fütoteraapia kasutamist; d) õpetavad linnastressi järgset taastumist looduslikes kohtades, looduses, turismitaludes; e) vahendavad (uusloodud) rahvausundite diskursusi ja uusi pluralistlikke mütoloogiaainelisi sulameid; f) õpetavad õige toitumise reegleid ja rahvusköögi roogade valmistamist.

\section{a) Traditsioonilise meditsiini rakendamine}

Tänapäeva rahva- ja täiendmeditsiin kasutab kohalikku ja selle kõrval globaalsesse trendi kuuluvaid täiend/alternatiivmeditsiini võtteid, mis muudab rahvaravi segmendi osaks laiemast tervikust. Näiteks pakkus Hundiallika talu 2017. aastal (Tarkustekool 2017) järgmisi kursusi: hiina meditsiin, jooga, ajurveda, imiku- ja lastemassaaž, raseduse kohta käiv info, eesti ja vene rahvameditsiin, eesti saun ja vene saun. Kursuste nimekirjas olid veel vene loodusravi võtted esivanemate ajal ja meie päevil. Osa tarkusekooli kursustest korraldati teistes keskustes, nagu näiteks Karepa ravimtaimetalus. Kursusi viisid läbi ka kutsutud lektorid, muuhulgas olid nende seas USAs elava indiaanlase - Lendava Kotka - loengud (Flying Eagel alias Ba'ag Da, Rupert Encinas, Lilleoru ökoküla ja kommuuni sõber), kursust esivanemate jõust viisid läbi Mikk Sarv ja Kristel Vilbaste.

Erinevate keskuste juures torkavad silma sihtrühmade ühisjooned: neist paljud on orienteeritud naistele, rasedatele, imikutele, probleemsetele lastele, liigeshaigusi ja muid kroonilisi haigusi põdevatele isikutele, ent paljude sihtrühm on perekond tervikuna. Kui vaadata tänast ametliku meditsiini pakutavat,

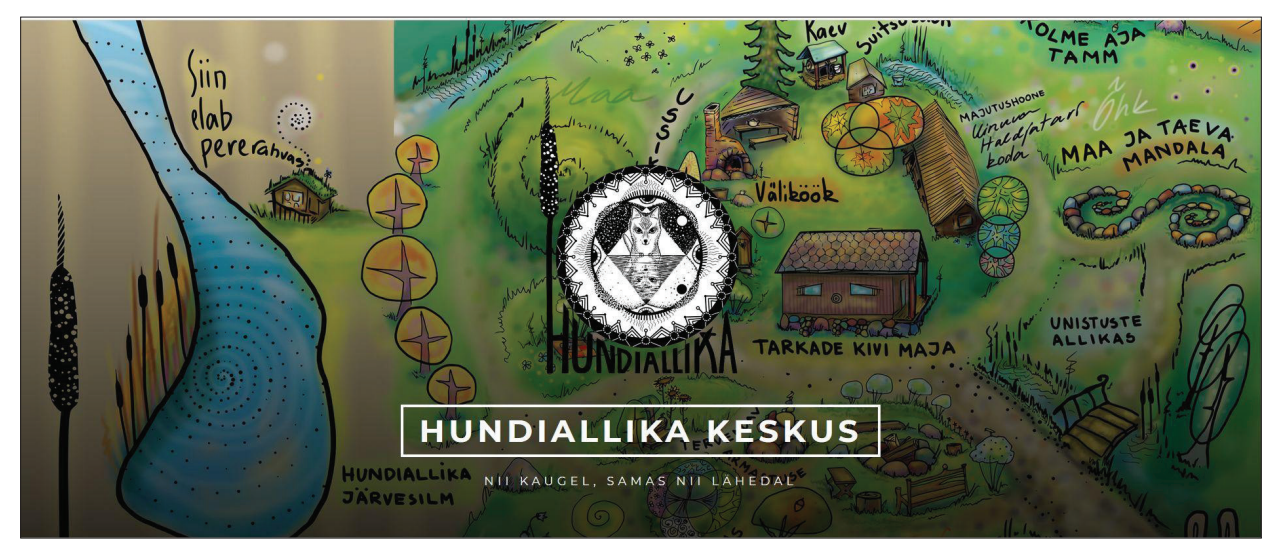


siis näeme seal rasedate koolitusi jm, ent keerukamate probleemidega on inimene suhteliselt üksinda, taastusravi võimalused on napid. Kuigi kursuste koosseisu analüüsides on näha, et prevaleerib võrdne füüsiline ja vaimne areng ja tasakaalustatuse pakkumine, on rõhutatud vaimset enesearendamist.

\section{b) Saun}

Saunal on läbi aegade olnud oluline koht teraapias ja ravimises, see on tähtis lõõgastumispaik. Viimane poolsajand on muutnud laialt kättesaadavaks korralikud kodused pesemisvõimalused, mis vähendab avalike saunade tähtsust. Ürituste ja spaateenuse osaks muutus saun eelmise sajandi lõpus, isiklik saun puhastamis- ja kommunikatsioonipaigana on tänasel päeval vähestel olemas. Spaateenused pakuvad soome-, türgi- jm saunu, moodsaid auru- ja leilisauna tüüpe, mis jätab kohaliku eripära varju. Samas on UNESCO toetusel taastatud suitsusaunatraditsioon kasvav turismitööstuse osa (Võsu \& Sooväli-Sepping 2012), mida toetavad Eda Veeroja suitsusauna kursused (http://www.mooska. $\mathrm{eu} /$ ).

Saunakursused ja ökospaa teenused rõhutavad sauna kui tervisetagatise teaduslikku põhjendatust ja algupärasust - tegemist on tõelise eesti või tõelise vene saunaga.

Esmapilgul tundub tõelise eesti sauna kursus tavalise saunakülastusena, kuid see toimub lektori juhendamisel ja toetusel, samuti selgitatakse seda uue kultuuriruumi võtmes ja tegevust sakraliseerides.

Saunanaine hõõrub laval lamaja keha meega sisse ja vihtleb korralikult läbi, kasutades erinevaid vihtlemisvõtteid ja lausudes roosisõnu. Viheldakse sobiva toimega ja kas naiste või meeste vihaga.

Peale vihtlemisseanssi lamatakse veel higistades laval, seejärel loputatakse ennast jaheda veega ning taastutakse, tundes vanade eestlaste "lovesse langemise" onnnistavat ja tervendavat tunnet. Saunarituaali lõpetuseks võitakse keha niisutavate ja noorendavate ürdiõlidega.

(Harmoonikum 2017, Maavägised 2017).

Rituaal imiteerib tavasaunas toimuvat, kuid on sakraliseeritud. Saunarituaali protseduuride järjekord, keha jahutamise-soojendamise rütm, karastamine külma veega (külmas veekogus, lumes pärast vihtlemist), saunakuumuses viibimine, jahutamine ja kehaline puhkus jahedas sauna eesruumis, vastastikune vihtlemine ja selja pesemine meenutavad sajanditepikkuseid kodutraditsioone. Suurte (nn täiskasvanute) ja väikeste (laste) vihtade ettevalmistamine ja kasutamine, kasevihtade kõrval tammest, kadakast, nõgestest jm vihtade 
kasutamine erinevate terviseprobleemide korral toimub traditsioonide raames. Külma veega ülevalamine on saanud enamasti uue ja teaduslikuma nimetuse - Kneippi vesiravi ${ }^{3}$. Lektor on samaaegselt ka pesija ja saunamees, kuid võrreldes tavasaunaga on sauna külastajale siin eraldatud passiivne roll. Talle räägitakse saunast kui puhkekohast, kus ei tohi vanduda, pruukida alkoholi jm - tutvustatakse traditsioonilise kultuuri tavanorme. Protseduurile lisandub (lisanditega) meega sissehõõrumine ja roosisõnade lausumine. Saunasõnade traditsioonilisse kompleksi kuulusid sauna teretamine, tänu- ja õnnistussõnad vihtlejale ja sauna kütjale, ka teistele ettevalmistajatele. Selja ja vahel kogu ihu vihtlemine kaassaunaliste poolt oli tavapraktika, millele vastati tänamise või tänusõnadega. Arstimissõnu kasutati ravimisel, nad ei kuulunud tavalise saunakülastuse juurde, arstimissõnad valiti vastavalt haigusele. Multifunktsionaalseid loitse sai kasutada ka teiste haiguste ravimiseks (Kõiva 2019). Raskemate haiguste ravimisel kasutati vahel ussi-, roosi- või valusõnu. Huvitav ja kohane on sauna kogemuse iseloomustamine väljendi "transsi langemine" abil. Hea saun on nii füüsiline kui vaimne kogemus.

Kokkuvõttes on muudatused tõlgenduses ja toimuvas tühised kui jätta välja nõiasõnad ja mõnel juhtumil terminite kaudu varasemate naturopaatia võtetega seostamine (näiteks Kneippi õpetusele toetumine eesti või vene tavandi asemel). Külastajal on saunalise ja selgituste saajana passiivne roll, kuid ta saab sissevaateid kunagi olulisse tervistamiskeskkonda ja kultuurinormidesse.

\section{c) Fütoteraapia}

Muutunud on ravimtaimede kasutamine, mis on tarbimise kõrval ka tootmissuund, hõlmates kasvatamise, töötluse ja turunduse osa. Selles vallas on tehnoloogiliste innovatsioonide kõrval (koristus- ja töötlustehnoloogia), tähtis uute toidutaimede toidukultuuri ja herbalistikasse juurutamine, taimeteadmiste kasutamine kultuuriruumi tõlgendamisel ja tutvustamisel. Tähtsaks vaimseks keskuseks on kujunenud näiteks Katrin Lukele kuuluv Karepa ravimtaimetalu (Karepa ravimtaimeaed 2019). Rõhutades taimede tähtsust, on Katrin Luke laiemalt tuntud uute toidutaimede (näiteks karulaugu) ning taimravi edendaja ja juurutajana (taimesegud nii kodumaistest kui võõrliikidest, ürdisool ja kuusevaigu-põhised salvid jne). Tema õpetustes on tajutav varasema traditsiooni tundmine:

Kuusevaigu salv parandab näpu-ja huulelõhed ja aitab herpese korral. Suvel kannalõhede ja putukahammustuste korral (Karepa ravimtaimeaed 2017). 
Lisaks ravimtaimetalu majandamisele osaleb ta fütoterapeudina põlistarkuste ja rahvaravi kooli õppeprogrammides ja terviseüritustel. Taimetarkusi edastavad ka Metsamoori ehk Irje Karjuse kursused, mille juurde kuulub loitsimine ja muud elemendid. Herbaatika ja Holistilise Fütoteraapia koolis on viis ravimtaimedele tuginevat põhiõppekava. Karjus on populaarsete teaberaamatute autor ja tervendava maastiku looja.

\section{d) Linnastressist taastumise koolitused looduse keskel asuvates turismitaludes}

Mõned kursused pakuvad alternatiivi linnatunnetusele: tähtsal kohal on kontakt loodusega, iseäralik kogemus väljaspool linlase mugavusi, ööbimine väljaspool moodsat kodu kas talus või telkides (naisteriituste kohta vt Kõiva 2011). Pakutakse linnakogemusest erinevaid rolle ja endasse süüvimise võimalusi, vaikuse laagreid, samuti oma võimete katsetamist ekstreemsetes oludes (soos ja laugastel käimise jm kursused).

Vaikuse ja oma isikliku kontseptsiooni otsingu laager Lõuna-Eestis Hundiallika talus $(2017)^{4}$ kutsus osalema kahepäevases laagris, mille käigus kasutati sisevaatluse, looduse vaatluse ja meditatsiooni võtteid, muuhulgas ka vaikust. Laagris viibimine kulges täielikus vaikuses, erandiks vaid arutlusring laagris viibimise alguses ja lõpus.

Laagri keskseks praktikaks on läbi kogu öö, õhtust hommikuni kestev eneseotsing looduses. Sellise praktika loojateks on Ameerika põlisrahvad, tänapäeval kasutatakse võtet laialdaselt erinevates vaimsetes praktikates. Sellise treeningu käigus võib leida vastused oma küsimustele, selgendada mõistust ning saadud selguse ja info alusel liikuda edasi tuleviku suunas.

Laagris kasutavate vaikuse praktikate seas võib loetleda mitmeid kaasaegses religioosses maailmapildis juurdunud praktikaid: oma puu, koha ja vaimse abilise otsing, suhtlemine loodusvaimudega ning kindlasti saun ja enesearendamise harjutused. Konkreetselt pakuvad nt Hundiallikal läbiviidavad kursused: meditatsiooni, "pime trumm" ("blind drum"), öist eneseotsingut (Visiooniotsingu (vision quest) ja vaikuselaager 2017; Vaikuselaager Kalanas 2015).

\section{e) Vahendus rahvausundite diskursuses, uues pluralistlikus ühinemises}

Kaasaegsed turismitalud ja tervisekeskused pakuvad vaimsust toetavat enesesse süvenemist, sõnastades selle kui seose vanade rahvauskumustega, samuti 
peetakse kalliks vanu ja taasloodud pühapaikasid. Näiteks eespool mainitud vaimsetel harjutustel oma puu ja hingelooma, kaitsja või oma koha otsingul on juured vanemates usundilistes kujutelmades, ehkki nad on ringiga jõudnud tagasi esoteeriliste liikumiste kaudu ja on omandanud uusi jooni.

Mitmed keskused pakuvad matkasid pühapaika koos rituaaliga. Üldjuhul antakse sellise käigu ajal selgitusi esivanemate kultuuri kohta, omistades neile uusi väärtusi, uut kultuurikonteksti. Samas lisab nn autentsus usaldusväärsust. Enamus kursustest ei vahenda autentset folklooritraditsiooni, vaid on selle loomingulised edasiarendused.

Näiteks on ravikeskus Harmoonikum (Pärimusretked 2017) pakkunud kultuurimatka pühasse hiide, osalemist rituaalides ja kombetalitustes, kaitsetootemite valmistamist; keha ja hinge tugevdamise rituaale (saunarituaalid, vana-eesti massaaž ja meeteraapia).

Mentaalselt lähedasi võimalusi pakub näiteks Muhu saarel paikneva Tihuse hobuturismi talu juht Martin Kivisoo - talu teeb matkasid pühapaikadesse traditsiooniliste kultuurirituaalide korraldamisega (Tihuse hobuturismitalu 2017), Krautmani terviseakadeemia tudengid külastavad pühakohti (Mäesepp 2015; Üks 2013; Peek 2011). Hiiekülastamise teenust ja vanade tavandite tõlgendusi pakub ka eesti loodususundi olulisemaid isikuid Ahto Kaasik oma MTÜ Põline Pere vahendusel.

Aastaid oli folkloorse kultuuri ja uuenduste sõlmpunktis Mikk Sarv (19512018), legendaarse rahvamuusikaansambli Hellero üks asutajatest (Sarv 2014). Alustanud Eestis Michael Harneri (1929-2018) stiilis tuumšamanismi kursusi, kasvas sellest unikaalne sulam, kus šamaanitrumm on ühendatud arhailise eesti regilauluga. Regilaulu alal oli Mikk Sarv fenomenaalne meister, lauljaimprovisaator, mis arvestades arhailist luule- ja keelevormi, on üsna keeruline ülesanne. Kristel Vilbaste meenutab:

Ta liitis sellele enda kogemused siberi jt põhjarahvaste juurest õpitul ja muidugi meie enda rahvapärimuse - muinaslood, regilaulud, rahvakalendri jpm. Aga põhiolemuseks on kolmeosaline maailmapilt, meelerännud trummi saatel ja looduskäigud (nn keskmise ilma rännud). Õpilasi on vähemalt pooltuhat olnud 2003. aastast. Aga ta alustas Marjuga juba 1990ndatel. Õpetuse tähtsamaks osaks on lood, mis saadakse meelerännul, nende jagamine ühises ringis ja selle kaudu õppimine. (EFITA 2019)

Viimaste aastate erikursusel ühendas Mikk Sarv folkloori isikliku kogemuse juttudega, kutsudes osalejaid meenutama oma lähedasi esivanemaid ja neist jutte vestma. "Esivanemate väe kursus" õpetas siduma erinevaid teadmisi, 
leidma üles teadmised sugulastest ning toetuma oma suguvõsale - see Mikk Sarve ja Kristel Vilbaste juhtimisel alanud kursus jätkub Kristeli käe all.

Kursuse tutvustus on omalaadne kreedo ja üldistus:

Kui vanasti räägiti tuulest, siis kõneldi vaimust. Paljud põlisrahvad teadsid, et igas tuulepuhangus võib teadja tajuda sõnumit esivanematelt. Tänuks saadud sõnumi eest lauldi selle esivanema isiklikku laulu, joigu, kelle poolt tuulepuhang tuli. See tagas hea edenemise ja õnne, siis oli esivanemate palvevägi sinuga kaasas kõigis tegemistes ja ettevõtmistes ning kõik tuuled puhusid alati soodsas suunas. (Esivanemate väe kursus 2017)

Kuna eelmised kursused võtsid üles ühe originaalsema läänemeresoome muusikastiili - joig - integreerimise eesti kultuuriruumi, siis on kohane meenutada kursusi, mis õpetatavad rituaaliks vajaliku pilli (näiteks trummi) valmistamist. Tavalise muusikateraapia kõrval eksisteerib innovatiivne heli- ja muusikateraapia, mis kujutab endast eraldi mahukat alateemat. Sageli langeb valik maailma erinevale rahvamuusikale, mis on ühendatud kaasaegsete muusikavooludega. Torupillitalus ja torupillimeistrite kodus kasvanud Triinu Taul iseloomustab oma stiili: innustavad meditatiivsus ja tuhandeaastaste runolaulukujundite sügav maailm, šamanism, saami joiud, bulgaaria rahvalaulud, tuva kurgulaulmine, tiibeti munkade palvemuusika, samuti paljude muude rahvaste rahva-ja rituaalmuusika.

T. Taul nimetab enda mõjutajatena klassikalist, pop- ja jazzmuusikat ning laia valikut vernakulaarseid stiile (“oma esivanemate" muusika) ja ülemaailmset sakraalmuusikat. Just "harmooniliste helide toimimise printsiipide tundma õppimine on teda ajendanud looma muusikat, milles segunevad vana ja uus omal sügaval ning huvitaval moel, mis on harmooniline ja kannab taotlust tasakaalustada ja tervendada" (Taul 2017).

\section{e) Tagasipöördumine endiste meditsiinivõtete juurde}

Eespool on korduvalt iseloomustatud võtteid, mis on kohalikule tervisekäitumisele tunnuslikud, nende edasiarendused või uuesti esile toodud ravivõtted, nt mee, mesilaste nõelamise ja sipelgate hammustamisega (Ninn 2011; Lill 2017) - mesilasemürgi- ja sipelgahappega. Arvestatavalt tegeldakse ka sõnamaagiliste tekstide õppimise ja loomisega loitsukursuste raamides, ent seegi on omaette pikem teema.

Kõrgelt väärtustatakse vanade võtete säilitamise traditsioone. Näiteks reklaamib tervisekeskuse Harmoonikum blogi mitmeid taas kasutusele võetud vanu ravimeetodeid ja annab neile uue, kaasaegse verbaalse vormi: "Meil olid 
omad energeetiliste kanalite mõjutusmeetodid. Nendest üks oli meemassaaž, teine - vana-eesti massaaž ja kolmas - hirudoteraapia" (Lill 2017).

Siinkohal märkigem, et muinas- ja keskaja meditsiinis kasutatud kaaniravi tuli Euroopas ravivõtete loetellu 1970. aastatel, Eestisse jõudis see 1980. aastatel.

\section{Kokkuvõte}

Jakob Hurt jaotab rahvauskumuste alaliikidena 1888. aastal: nõidade laulud ja sõnad (magischen Lieder und Sprüche) ja rahva arstimised (Volkstümliche Heilmethoden und Zauberkuren), mis koosneb kahest poolest (Hurt 1888). Nüüdne rahvapärimusvõtete hulk on märgatavalt laienenud. Rahva-ja loodusmeditsiini kursusi ja praktikume korraldavad erineva taustaga inimesed farmakoloogiaprofessoritest meedikuteni ja nende tõlgendused on sama pluralistlikud ja innovatiivsed kui sellist haridust mitteomavatel isikutel. Paljudel praktikutel on kõrgharidus erinevates valdkondades, kas teaduskraad metsanduses, bioloogias, kultuuriteadustes, kuid on ka sotsiaaltöötajaid ja inimesi, kes on saanud oskused ja sertifikaadid loodus- ja rahvaravi kursustel. Tuleb esile tuua isiklikku panust teadmiste omandamisse: paljud Eestis õpetajate ja koolitajatena tegutsevad inimesed on käinud omale õpetajaid otsimas otse Hiinast, Indiast, Nepalist, Venemaalt, soome-ugri põlisrahvaste ja indiaanlaste juurest - oskusi on omandatud vahetult elavast traditsioonist ja koolkondade esindajatelt. Olulisel kohal on kreatiivne arenduslikkus, kogemusliku ning lokaalse põimimine üldisemasse praktikasse. Täiesti uut laadi kogemust pakuvad "Selgeltnägijate tuleproovi" saates esinejad oma ringreiside ja kohtumistega, nad on tõusnud koguni arvamusliidri positsiooni.

Kursuste korraldajatel kui isiksustel on tähtis roll, mis seisneb autoriseeritud pluralistlike vaadete esitamises, medikamentide, ravivahendite ja maailmavaadete sünteesimises. Parimad koolitajad ja õpetajad ei ole vahendajad, vaid pigem uute suundade autorid ja loojad.

Mõnedel täiendmeditsiini suundadel on suur ühiskondlik toetus (joogapäevad ja -festivalid, erinevad sellelt põhjalt lähtuvad koolitused, hiina meditsiin). Traditsioonilise meditsiini mõiste ühendab endas laialdast, globaalselt tunnustatud suundade (aroomiteraapia, ajurveda, Hiina meditsiin) valimit, vanade ravivõtete taassündi, samuti kohalikke eesti (ja vene) saunakultuuri ja rahvameditsiini võtteid ja nende variante laialdases mõttes. Märgatav on diagnostiliste ja terapeutiliste protseduuride mitmekülgsus, mis väljendub ka kursuste sisus ja praktikas. 
Seekordne taimeravimoodul sisaldas küll kõike - käisime Tammetsōõris ja Kristel Vilbaste töötoas, Hundiallika suitsusaunas, Süvahavva loodustalus, Mustjörves ujumas, Ootsipalu hiiglaseid kallistamas ja muidugi tegime salve ja mähiseid ja õppisime taimi tundma ja isegi joonistama ja. Ja ilmataat oli ka meie poolt. (EFITA 2019)

Osalejate kohta kehtivad arvatavasti Kleini jt (2015) üldistused: "paljudes maades, sh Šveitsis, Saksamaal, Itaalias, Ühendkuningriikides, Kanadas, USAs ja Austraalias on peamised kursustel osalejad naised, keskealised, inimesed keskmisest suurema haridustasemega või suurema sissetulekuga. Efektiivsus ja tervise-haiguse diskursus vajavad tasakaalustatud uurimistööd".

Kogu tervise-ravimise-meetodite protsess on üleminekuala, kus rahvameditsiini üldpraktikasse kantakse teadmisi ametlikust biomeditsiinist, valikuid alternatiiv- ja täiendmeditsiini teadmiste varamust. Taas on pöördutud 19. ja 20. sajandi õpetuste juurde. Selle protsessi tulemusel küllastatakse rahvameditsiinist saadud teadmised uute mõistete, praktikate ja medikamentoossete lahendustega. Seejuures ei ole kaugeltki mitte kõik integreeritav - kultuuriruumis eksisteerivad alternatiivsuunad ka omaette komplementaarse praktikana.

Lõpetuseks tasub märkida, et moodsas terves eluviisis rakendatakse kõige erinevamaid folkloorialaseid teadmisi, haiguste profülaktika ja ennetamise võtteid: saunakultuuri, fütoteraapiat, toitumiskultuuri, linnastressist vabanemist looduses, mõningaid taasjuurutatud võtteid (ravi mesilas- või sipelgamürgiga, uriini- ja kaaniravi, kuufaasidega arvestamine jm). Luuakse kohaliku rahvameditsiini võtetele uusi kultuurilisi tõlgendusi, psüühilise tasakaalu saavutamiseks ja ravimiseks kasutatakse mh rahvamuusikat ja jutustamist, mis Eesti kontekstis on uudne ja erineb meditsiinipraktikas kasutatavast jutustamisteraapiast.

Üks olulisi tähiseid on panus vaimsesse arengusse ehk teisisõnu toimetulekusse tänases ühiskonnas. Loodus- ja rahvameditsiinis (väljaspool ametlike meditsiinikursuste raame) toimuvad protsessid sarnanevad rahvusvaheliste kultuuriilmingutega ning on ülemaailmse tervisekäitumise ja tervena elamise osa. 


\section{Tänuavaldus}

Artikkel on laiendatud versioon šamanismi ja mütoloogia-uurija Mihaly Hoppali teadustööle mõteldes ja tema sünnipäeva auks kirjutatud uurimusest, avaldatud 2017 inglise ja vene keeles (vt Kõiva 2017a; 2017b). Tänan kõiki, kes kirjutise kohta soovitusi jagasid.

Artikkel on seotud uurimisteemaga IUT 22-5 (Folkloori narratiivsed ja usundilised aspektid) ja Eesti-uuringute Tippkeskusega TK 145.

\section{Kommentaarid}

1 Tikk 2005; Pau 2017, lähedast problemaatikat on käsitlenud nt Lubi \& Uibu \& Koppel 2018.

Reseach Gate annab üle 20000 teadusartikli, mis uurivad täiend- ja alternatiivmeditsiini problemaatikat, kuid käesolevas artiklis viidatakse neist mõnele.

Üleüldise rünnaku alla sattus igasugune alternatiivne mõtteviis 2018. aastal seoses MMS juhtumiga, mis aktiveeris poliitikuid, aga ka usutegelasi. Euroopa akadeemiate teadusnõukogu (EASAC) ja Euroopa meditsiiniakadeemiate föderatsiooni (FEAM) hoiatavad traditsioonilise hiina meditsiini reguleerimata kasutamise eest. Euroopa teaduste ja meditsiini akadeemiad kutsuvad üles tõenduspõhisele diagnoosimisele ja ravile vastuseks sellele, et Maailma Tervise Organisatsioon (WHO) on lisanud traditsioonilise hiina meditsiini oma raamistikku. WHO on sõnastanud tervise kui füüsilise, vaimse ja sotsiaalse heaolu ilma haiguse olemasoluta.

${ }^{2}$ Frederick Dunni termin kosmopoliitne meditsiin leidis heakskiidu ja laialdase kasutuse järgnevatel kümnenditel meditsiiniteadustes ja antropoloogias (vt ka Ebrahimnejad 2009; Ohnuki-Tierney 1984 jt).

3 Sebastian Kneipp (1821-1897) - loodusravi, sh vesiravi oluline eestkõneleja, naturopaatia eelkäija.

${ }^{4}$ Hundiaugu talu retriidi- ja koolituskeskus Võrumaal tegutseb aastast 2013, perenaine on ennast koolitanud Nepalis jm.

\section{Kirjandus}

Abbott, Ryan B. \& Hui, Ka-Kit \& Hays, Ron D. \& Mandel, Jess \& Goldstein, Michael \& Winegarden, Babbi \& Glaser, Dale \& Brunton, Laurence 2011. Medical Student Attitudes toward Complementary, Alternative and Integrative Medicine. Evidence-Based Complementary and Alternative Medicine (doi: 10.1093/ecam/nep195).

Abiline, Toomas 2013. Uue vaimsuse eelkäijad: antroposoofia, teosoofia, vabamüürlus ja parapsühholoogia Eestis 1918-1940. Uibu, Marko (toim). Mitut usku Eesti III: Uue vaimsuse eri. Tartu: Tartu Ülikooli kirjastus, lk 37-78. 
Astin, John A. 2000. The Characteristics of CAM Users: A Complex Picture. Kelner, Merrijoy \& Wellman, Beverly \& Pescosolido, Bernice \& Saks, Mike (toim). Complementary and Alternative Medicine - Challenge and Change. London: Routledge, lk 101-114.

Cant, Sarah \& Sharma, Ursula 1999. A new medical pluralism? Alternative medicine, doctors, patients, and the state. London: Routledge.

Coulter, Ian \& Willis, Evan 2007. Explaining the growth of complementary and alternative medicine. Health Sociology Review 16, lk 214-225 (doi: 10.5172/hesr.2007.16.3-4.214).

Dunn, Frederick 1976. Traditional Asian Medicine and Cosmopolitan Medicine as Adaptive Systems. Leslie, Charles (koost). Asian Medical Systems: A Comparative Study. Berkeley, CA: University of California Press.

Ebrahimnejad, Hormoz 2009. The Development of Modern Medicine in Non-Western Countries: Historical Perspective. Abington Oxon \& New York: Routledge.

EFITA 2019 = Põlistarkuste ja Rahvaravikool is at Hundiallika Retriidi-ja koolituskeksus, 14. august. Facebook (https:// www.facebook.com/tarkustekool/posts/2763283000366653 1. detsember 2019).

Esivanemateväe kursus 2017 =Esivanemate väe kursus Mikk Sarveja Kristel Vilbastega 24. juuli 2017. Facebook (https://www.facebook.com/events/317228532032235/-14. november 2019).

Falci, Laura \& Shi, Zaixing \& Greenlee, Heather 2012. Multiple Chronic Conditions and Use of Complementary and Alternative Medicine Among US Adults: Results From the 2012 National Health Interview Survey. Preventing Chronic Disease 2016 (13:150501) (doi: 10.5888/pcd13.15050).

Foucault, Michel 2003 [1963]. The Birth of the Clinic. An archeology of medical perception, London: Routledge Classics.

Harmoonikum 2017. Harmoonikum (https://harmoonikum.ee/avaleht/kumblustuba/eheeesti-saun/ - 14. november 2019).

Hundiallika keskus 2017. Hundiallika keskus (http:/hundiallika.ee/ - 14. november 2019).

Karepa ravimtaimeaed 2019 = Karepa ravimtaimeaed (http://www.ravimtaimeaed.ee/ 14. november 2019).

Klein et al. 2015 = Klein, Sabine D. \& Torchetti, Loredana \& Frei-Erb, Martin \& Wolf, Ursula 2015. Usage of Complementary Medicine in Switzerland: Results of the Swiss Health Survey 2012 and Development Since 2007. PLoS ONE 10 (10): e0141985 (doi: 10.1371/journal.pone.0141985).

Krug Zhizni 2015. Mezhdunarodnaia konferentsiia po traditsionnym avtorskim i nauchnym tekhnologiiam dlia zdorov'ia, krasoty i dolgoletiia. Krug Zhizni II (http:// congressminsk.by/congress2jjuly2015/ - 19. november 2019).

Kõiva, Mare 2014. Naistepühad ja -riitused - etnilistest kultuuritavadest uusreligioossete rituaalideni. Kõiva, Mare (toim). Maailm ja multitasking (2. parandatud ja täiendatud trükk). Tänapäeva folkloorist 10. Tartu: Eesti Kirjandusmuuseumi Teaduskirjastus, lk 133-162. 
Kõiva, Mare 2017a. Cosmopolitan Medicine: Courses Uniting Naturopathy and Folk Medicine. Mátéffy, Attila \& Szabados, György (toim). Shamanhood and Mythology. Archaic Techniques of Ecstasy and Current Techniques of Research. Budapest: Hungarian Association for the Academic Study of Religions, lk 243-254.

Kõiva, Mare 2017b. Global'naia narodnaia meditsina: kursy prirodnoi terapii i narodnoi meditsiny. Kharitonova, Valentina (peatoim). Meditsinskaia etnografiia: sovremennye podkhody $i$ kontseptsii. Trudy po meditsinskoi antropologii. Moskva: OOO Pablisiti, lk 253-272.

Kõiva, Mare 2019. Eesti loitsud. Arstimissõnad. I. Tartu: EKM Teaduskirjastus.

Leia end 2017. Esoteerikafestival "Leia end - naidi sebja" IX festival: Põhjala traditsiooni ja ruunide päev-ruunide oraakli öö. Leia end (https://fienta.com/et/leiaend-naidisebja 19. november 2019).

Lill, Ene 2017. Harmoonikumi blogi (https://harmoonikum.ee/?s=blogi - 19. november 2019).

Lubi, Kadi \& Uibu, Marko \& Koppel, Katre 2018. Teaduslikult alternatiivmeditsiinist. Eesti Arst 97 (8), lk 409-415 (doi: 10.15157/ea.v0i0.14248).

Maavägised 2017. Saun - see on osa eestlaste ürgolemusest. Maavägised (http://www. maavägised.ee/ee/blogi/130-saun-see-on-osa-eestlaste-yrgolemusest - 14. november 2019).

Mäesepp, Merle 2015. Pärimusmeditsiini õpilased Lahemaal hiisi avastamas. Hiiepaik (http://hiiepaik.ee/uncategorized/parimusmeditsiini-opilased-kulastasid-lahemaalasuvaid-puhapaikasid/ - 14. november 2019).

Ninn, Eger 2011. Pärimusmeditsiin - ravitarkused aastasadade tagant, Postimees 9. veebruar (http://tervis.postimees.ee/385303/parimusmeditsiin-ravitarkusedaastasadade-tagant - 19. november 2019).

Nissen, Nina 2011. Challenging perspectives: women, complementary and alternative medicine, and social change a journal for and about social movements. Interface 3 (2), lk 187-212 (http://www.interfacejournal.net/wordpress/wp-content/uploads/2011/12/ Interface-3-2-Nissen.pdf - 19. november 2019).

NN 2015 = Revolutsioon meditsiinis: järsk pööre tagasi rahva- ja pärimusmeditsiini poole. Telegram, 7. märts 2015 (http://www.telegram.ee/toit-ja-tervis/revolutsioonmeditsiinis-jarsk-poore-tagasi-rahva-ja-parimusmeditsiini-poole-20. november 2019).

Ohnuki-Tierney, Emiko 1984. Illness and Culture in Contemporary Japan. Cambridge: Cambridge Scholarly Press.

Pau, Aivar 2017. Kaljulaid sattus guugeldades uhhuu-kultuuri otsa ja on mures. Postimees (https://tehnika.postimees.ee/4305027/kaljulaid-sattus-guugeldades-uhhuukultuuri-otsa-ja-on-mures - 14. november 2019).

Peek, Ingrid 2011. Alar Krautmann, Hallo, kosmos! 06. veebruar (https://arhiiv.err.ee/ vaata/hallo-kosmos-hallo-kosmos-alar-krautmann - 24. juuni 2017).

Pärimusretked 2017. Harmoonikum (http://harmoonikum.ee/parimusretked-2/ 24. juuni 2017, ei ole enam leitav). 
Sarv, Mikk 2014. Hellero - Tartu vaimu särin. Tallinn: Cum laude.

Tan, Michael L. 1989. Traditional or transitional medical systems? Pharmacotherapy as a case for analysis. Social Science and Medicine 29 (3), lk 301-307.

Tarkustekool 2017. Põlistarkuste ja rahvaravi kool (http://www.tarkustekool. ee/ -14 . november 2019).

Taul, Triinu 2017. Triinu Taul. Kodulehekülg (http://www.triinutaul.com/en/minust/ 14. november 2019).

Tihuse Hobuturismitalu 2017. Ancient culture. Tihuse hobuturismitalu (kodulehekülg) (http://www.tihuse.ee/en/muinaskultuur/ - 19. november 2019).

Tikk, Arvo 2005. Arstid ja alternatiivmeditsiin. Eesti Arst 5, lk 294-296.

Toupin, April \& Gaboury, Isabelle 2013. A survey of Canadian regulated complementary and alternative medicine schools about research, evidence-based health care and interprofessional training, as well as continuing education. BMC Complementary and Alternative Medicine 13 (374) (doi: 10.1186/1472-6882-13-374).

Uibu, Marko 2013. Sissejuhatus: Uue vaimsuse uurimisest ning kogumikust "Mitut usku Eesti III". Uibu, Marko (toim). Mitut usku Eesti: Uue vaimsuse eri. Tartu: Tartu Ülikooli kirjastus, lk 7-17.

Vahesaar, Tauri-Viljar 2016. Joogateraapia kui alternatiivravi erinevate haiguste korral. Bakalaureusetöö. Tartu: Tartu Ülikool, Kehalise kasvatuse ja spordi õppekava (https:// dspace.ut.ee/bitstream/handle/10062/56342/Vahesaar_TauriViljar.pdf?sequence=1\&is 19. november 2019).

Vaikuselaager Kalanas 2015. Vaikuselaager. Ha Tha joogatuba (kodulehekülg) (http:// joogatuba.ee/vaikuselaager - 19. november 2019).

Visiooniotsingu- (vision quest) ja vaikuselaager 2017 (https://www.facebook.com/ events/hundiallika-retriidi-ja-koolituskeskus/visiooniotsingu-vision-quest-javaikuselaager/418266955182051/ - 19. november 2019).

Walsh, Zack 2016. The Global Ecovillage Network: Process Philosophy and Ecological Theology Applied. Jesus, Jazz, and Buddhism, 23. mai (praegu kättesaadav https:// www.academia.edu/25552897/The_Global_Ecovillage_Network_Process_Philosophy_ and_Ecological_Theology_Applied - 19. november 2019).

Wilse, James 2009. Medical Discourse. Annual Review in Anthropology 38, lk 199-215 (doi: 10.1146/annurev-anthro-091908-164450).

Üks 2013. Alar Krautman - pärimuslik mees tänases päevas. Üks 16. märts (https:// alkeemia.delfi.ee/hallokosmos/uusmaailm/ajakirja-uks-aasta-julge-2011-on-alarkrautman?id=69696327 -19 . november 2019). 


\title{
Summary
}

\section{Courses uniting naturopathy and folk medicine}

\author{
Mare Kõiva \\ Leading Researcher at the Department of Folkloristics \\ Estonian Literary Museum, Estonia \\ mare@folklore.ee
}

Keywords: complementary medicine, cosmopolitan medicine, hereditary medicine, pluralistic medicine

The article elaborates on Dunn's views on cosmopolitan medicine and broadens the term by applying it to a neighbouring field - cosmopolitan hereditary medicine. An overview is given of the movement's contemporary trends, including esoteric teachings, homoeopathy, yoga, Chinese medicine, Ayurveda, music therapy, flower and aroma therapy as well as herbal medicine making use of new herbs - all of which have been introduced to Estonia via cultural cosmopolitanism. An outstanding feature is the attention given to a person's holistic aspect, development of mentality and health behaviour.

There is ongoing institutionalisation of traditional and complementary medicine practice, while educational courses and healing seances have moved from the city to rural health and tourism centres. One of the key values attributed to knowledge is its age, its ancient nature enabling the combination of different trends. Opportunities offered by local (vernacular) medicine are emphasised and new cultural interpretations are added. Mainstream trends are as follows: a) local complementary or alternative medicine as a segment of local folk medicine; $b$ ) health behaviour, lifestyle preventing or warding off disease (sauna culture, herbal medicine, release from city stress in natural surroundings, original music therapy, etc.); and c) introduction into the alternative worldview, mental self-development, and pluralistic folk belief.

Mare Kõiva $(\mathrm{PhD})$ Eesti Kirjandusmuuseumi folkloristika osakonna juhtivteadur, osakonnajuhataja, Eesti-uuringute Tippkeskuse (CEES) juht. Huvikeskmes on olnud rahvausund ja mütoloogia, hõlmates loitse ja meediumeid, haldjapärimust, isiku- ja aheljutte. On uurinud rahvaravitsejaid, erinevaid internetikogukondi, rituaalse aasta mõjutegureid ning infotehnoloogia kasutamist folkloristikas. Praegu on ta keskendunud mütoloogiale ja rahvajuttudele.

Mare Kõiva (PhD) is Leading Researcher at the Department of Folkloristics at the Estonian Literary Museum, Estonia, and Head of the Centre of Excellence in Estonian Studies. She has published several monographs and edited various books (incl. Estonian Incantations; co-edited Mission Possible (2018), 
Balkan and Baltic Studies (2017)). She has also written a wide range of articles and chapters on folk legends and beliefs, ethnomedicine, and the ritual year. Her current research focuses on mythology and belief narratives, human/nonhuman relationships, and incantations.

mare@folklore.ee 